\title{
Cancer-Inducing Mechanisms of Representative Sexually-Transmitted Infection Pathogens
}

\author{
Emmanuel Sokefun*, Olayemi Akinnola \\ Department of Biological Sciences, Covenant University, Ota, Nigeria \\ Email address: \\ emmanuel.sokefun@stu.cu.edu.ng(E. Sokefun) \\ ${ }^{*}$ Corresponding author
}

\section{To cite this article:}

Emmanuel Sokefun, Olayemi Akinnola. Cancer-Inducing Mechanisms of Representative Sexually-Transmitted Infection Pathogens. Cell Biology. Special Issue: Cell Death and Mechanisms in Cancer. Vol. 8, No. 1, 2020, pp. 12-21. doi: 10.11648/j.cb.20200801.13

Received: August 25, 2019; Accepted: February 27, 2020; Published: July 22, 2020

\begin{abstract}
The causal organisms of the numerous sexually transmitted infections (STIs) may be bacteria, viruses, fungi or protozoa. Apart from the known STIs these organisms cause, along with their accompanying physical, psychological and social effects, these organisms have also been implicated in oncogenesis. Each pathogen has its unique mechanisms of action, however, one representative organism was examined for each of the groups of microbes that cause STIs, namely: viruses, bacteria, fungi and protozoa, to show their oncogenic association. The human papillomavirus, which causes genital warts, is associated with oropharyngeal, cervical, anogenital, testicular and prostate cancer by the actions of the E5, E6 and E7 oncogenes, which have different functions. Chlamydia trachomatis, the etiological agent of Chlamydia infection, is linked to lymphogranuloma venereum, trachoma, cervical, and ovarian cancers by squamous cell metaplasia, and by the inhibition of apoptosis factors: caspase 3 and mitcochondrial cytochrome c; which consequently inhibits apoptosis. Candida albicans, the causal organism of thrush in the mouth and the vagina, could cause cancer by producing carcinogenic by-products, triggering inflammation, molecular mimicry, and induction of the TH17 response. Trichomonas vaginalis, the protozoon which causes trichomoniasis, is known to cause the influx of pro-inflammatory molecules: chemoattractant protein-1, interleukin-8, and leukotriene B4, d neutrophils, and IL-6, and this may play a role in carcinogenesis. Expression of the oncogenes PIM1, HMGA1, and COX-2 by T. vaginalis has also been associated with the onset of cancer. Vaccination, healthy lifestyles, a mutually-monogamous sexual relationship, completing treatment regimen, use of sterile medical equipment, and not sharing sharp or invasive materials, are recommended in prevention and control of the STI pathogens and consequently, the cancers they cause.
\end{abstract}

Keywords: Sexually Transmitted Infections, Cancer, Oncogene, Inflammation

\section{Introduction}

Sexually-transmitted infections (STIs) are infections that can be transferred from an infected host to another host which may be infected or uninfected, during sexual intercourse-vaginal, anal, or oral. There is a long list of different STIs in the world today, among which are: HIV/AIDS (caused by the human immunodeficiency virus), genital warts (human papillomavirus), gonorrhoea (Neisseria gonorrhoeae), genital herpes (herpes simplex virus), syphillis (Treponema pallidum), bacterial vaginosis (Gardnerella vaginalis), Chlamydia infection (Chlamydia trachomatis), Pelvic Inflammatory Disease (PID) (Neisseria gonorrhoeae and Chlamydia trachomatis), viral hepatitis, Zika (Zika virus), and trichomoniasis (Trichomonas vaginalis), to mention a few [1].

Different STIs cause their varied signs and symptoms in the organs they infect. They cause physical, social, and emotional problems in the infected individual, and may also cause physical pain $[1,2]$. Parts of the body mostly affected by STIs include the mouth, face, throat, vagina, penis, urinary tract, vulva, testicles, prostate, colorectal and anal region, liver, and, of great consequence, the circulatory system [1]. Some directly damage the blood cells and/or deplete the immune system, which will allow them become systemic [1].

Cancer on the other hand, is a condition that arises when the cells of the body begin to divide at an abnormally high 
rate without cell death, and may eventually spread to adjacent tissues, such that the condition that began in a single cell could become systemic [3]. Cancer is a genetic disease, which means that changes in genes, particularly how they grow and divide, can trigger cancer [4]. When cells become cancerous, the cells that ought to die normally would continue to live beyond their regular life span thereby, causing crowding and toxicity.

Sometimes, cancer cells can travel within the body $[4,5]$. For example, cells in the breasts can become cancerous, but travel to the lungs and continue their growth there [4]. However, since they are originally breast cells and not lung cells, the individual is still regarded as having breast cancer. In essence, the cancer will be called lung cancer only on the condition that lung cells initially turned cancerous [4].

Some cancers form lumps in the body. These lumps are said to be "malignant" when they invade other tissues [4]. Other types of cancers, for example, leukaemia, do not form lumps, but develop in the blood cells and in other body cells [4]. However, not all lumps present in or on the body of an individual are caused by the presence of cancer. Lumps that are not present due to cancer are said to be "benign" [4]. They can be harmless when located on most parts of the body, but when located on the brain, they can be lifethreatening [4].

After ischemic heart disease and stroke, cancer is the third leading cause of mortality in the $21^{\text {st }}$ Century [6]. Of the 56.4 million deaths recorded in the year 2015 alone, cancer alone accounted for 8.8 million deaths out of 14 million new cases of cancer in the same year [6]. This means that 1 out of every 6.14 deaths recorded, or a $16.29 \%$ death rate, was due to cancer [6-7]. The WHO projects that in the next two decades, this rate will rise by $70 \%$. About $70 \%$ of all cancer-related deaths are recorded in low- and middle-income countries [6].

Many factors can predispose one to cancer. Genetic factors play a very important role. Other factors include: high body mass index, consumption of carcinogens, low fruit and vegetable intake, a sedentary lifestyle, activity of parasites, smoking, alcohol abuse, and contact with carcinogenic chemicals [8].
Many sexually-transmitted pathogens have been associated with cancer. Therefore, in this review, one virus, one bacterium, one protozoon, and one fungus have been selected to represent members of their respective groups, although, individual members of each group have their own unique mechanism(s). Selecting a member from each group is to indicate that at least one member of each group has been associated with oncogenesis and the mechanism should not be used to generalize for all members of the group. The specific mechanisms of action that the representative members employ in causing cancer will be discussed.

\section{STIs as Predisposing Factors to Cancer}

There are a number of STIs that lead to cancer in the different organs of the body. Though not all cases of STI infection lead to cancer, several cases have been recorded [9]. Many of such infections that lead to cancer are caused by either bacterial, viral, fungal, protozoan or helminthic pathogens. Such pathogens are called "oncogenic". De Martel et al. (2012) [9] state that $16 \%$ of all cancers are caused by bacteria and viruses alone.

Of all the cancers that affect the reproductive system, majority are of STI origin [3]. The parts of the body which often develop cancer are the same as the ones that are colonized by the pathogens. By extension, the parts of the body most commonly affected by STI pathogens are those that can be colonized during sexual contact. These would include: the breasts, penis, vagina, penis, rectum, prostate, cervix, mouth and throat.

The action of the causal pathogens of the STI, coupled with the reaction of the body, and other factors like genetics, the status of the immune system, and the cellular responses, are what trigger cancer.

Although the pathogens may cause several different diseases, only specific STIs and pathogens that have a carcinogenic potential have been included in table 1 .

Table 1. Some disease pathogens, along with the infections and cancers they cause.

\begin{tabular}{|c|c|c|c|}
\hline $\begin{array}{l}\text { Type of } \\
\text { Organism }\end{array}$ & Specie & Infection Caused & Cancer Caused \\
\hline \multirow[t]{7}{*}{ Bacteria } & Helicobacter pylori & Stomach and intestinal ulcers & $\begin{array}{l}\text { Mucosa-associated lymphoid tissue (MALT) lymphoma [10- } \\
\text { 11] stomach/gastric adenocarcinoma [12-14] }\end{array}$ \\
\hline & Escherichia coli $\mathrm{NC} 101$ & Diarrhea, fever, abdominal pain & Bladder cancer $[15]$, Colorectal cancer $[13,16]$ \\
\hline & Neisseria gonorrhoeae & Gonorrhea & Male bladder cancer [17], Prostate cancer [18] \\
\hline & Chlamydia trachomatis & $\begin{array}{l}\text { Chlamydia infection, nongonococcal } \\
\text { urethritis, cervicitis, salpingitis, } \\
\text { trachoma, pelvic inflammatory disease }\end{array}$ & $\begin{array}{l}\text { Cervical cancer [19], ovarian cancer [20-21] } \\
\text { lymphogranuloma venereum [22] }\end{array}$ \\
\hline & Mycoplasma spp. & Pelvic inflammatory infection & $\begin{array}{l}\text { Prostate cancer [23-25] gastric carcinoma [23, 26], } \\
\text { oesophageal cancer [23], lung cancer [23], breast cancer [23, } \\
\text { 27] renal cell carcinoma [28] }\end{array}$ \\
\hline & $\begin{array}{l}\text { Streptococcus galloylyticus } \\
\text { (formerly } S . \text { bovis) }\end{array}$ & $\begin{array}{l}\text { Colorectal infection, urinary tract } \\
\text { infection }\end{array}$ & Colorectal cancer [29] \\
\hline & Salmonella typhi & Typhoid fever & $\begin{array}{l}\text { Gallbladder cancer/hepatobiliary carcinoma [30-31], colon } \\
\text { cancer [32] }\end{array}$ \\
\hline Viruses & Human papillomavirus & Hepatitis & $\begin{array}{l}\text { Vulvar cancer, oropharyngeal cancer, cervical cancer, penile } \\
\text { cancer, anal cancer [33] }\end{array}$ \\
\hline
\end{tabular}




\begin{tabular}{llll}
\hline $\begin{array}{l}\text { Type of } \\
\text { Organism }\end{array}$ & Specie & Infection Caused & Cancer Caused \\
\hline & Hepatitis B virus & Hepatitis & Hepatocarcinoma [33] \\
& Hepatitis C virus & Hepatitis & Increases the risk of contracting Kaposi's sarcoma, anal \\
& & Immunodeficiency, Acquired & $\begin{array}{l}\text { cancer, lung cancer, liver cancer, mouth cancer, throat } \\
\text { cancer }\end{array}$ \\
& HIV/AIDS & Immunodeficiency Syndrome & Primary effusion lymphoma, Kaposi's sarcoma [35] \\
& Kaposi's sarcoma herpesvirus & Kaposi's sarcoma & Cervical cancer, Burkett's lymphoma [36] \\
& Herpes Simplex Virus & Genital herpes & Adult T-cell lymphoma [33] \\
& Human T-Lymphotrophic Virus & Adult T-cell leukemia, lymphoma & Nasopharyngeal cancer, Burkitt's lymphoma, Hodgkin \\
lymphoma, stomach cancer [33] & Breast cancer [37] mucoepidermoid carcinoma, prostate \\
& Epstein-Barr Virus American & Infectious mononucleosis & Any part [40] unspecified [41] \\
& Human cytomegalovirus & Cytomegalovirus infection & Prostate cancer [42-43] \\
\hline
\end{tabular}

Each member of a group has its unique mechanism of action in inducing cancer, and is only used to indicate that at least one member of the group has been recorded to possess oncogenic potential.

\subsection{Sexually-Transmitted Viruses Causing Cancer: HPV as a Representative Member}

The Human Papillomavirus (HPV) is the general name for more than 150 different sexually-transmitted viruses grouped together, and given identifying numbers to help tell them apart from other members of the group. The number of a given member of the group is also called its type. The virion has double-stranded DNA, a non-enveloped, icosahedral capsid, with its genome approximately 8,000 base pairs [44].

Members of this group are known to cause warts in various parts of the body, but more importantly, some members are highly disreputable for causing cancer. HPVs have been known to cause cancer in any part of the body where they can successfully colonize and remain [45]. These would include: the tonsils, throat, oropharynx, vagina, rectum, vulva, penis, testicles, cervix, and the anus [45]. HPV can be acquired through any form of sexual intercourse, and the pathogen can remain asymptomatic at the infection site for years, making it undetectable until it manifests $[3,45]$. In some cases, the virus leaves the patient, but in other cases, it leads to warts, and may later lead to cancer [45].

Most HPV infections clear off naturally, but the reality is that many other cases degenerate to the clinical case, and some of those cases lead to cancer [46]. The United States National Cancer Institute (2015) [45] further released that $95 \%$ of all anal cancer, $70 \%$ of all cervical cancer, $70 \%$ of oropharyngeal cancer cases, $65 \%$ of all vaginal cancer, $50 \%$ of all vulvar cancer, and $35 \%$ of all penile cancer cases are caused by the human papillomavirus alone, and only two types - the type 16 and type 18 are responsible for majority of these cases. About 493,000 new cases of cervical cancer alone are diagnosed annually, and approximately 274,000 deaths are recorded annually due to invasive cervical cancer [47]. As such, this virus is a very significant contributor to the pool of cancer and worldwide mortality.

Three oncoproteins of the HPV are implicated in oncogenesis in normal cells: the E5, E6, and E7 geneencoded proteins [47-48]. The DNA of this virus embeds itself in the host cell's genome, and this gives it great control over the cell and enables its genes propagate and express themselves [49].

The E5 protein inhibits apoptosis of infected cells induced by hydrogen peroxide, by stimulating ubiquitinproteasome-mediated degradation of bax (bax gene is the apoptosis regulator) in human cervical cancer cells [50]. It is also understood that the E5 associates with intracellular membranes and activates receptor tyrosine kinases, such as platelet growth factor receptor through a liganddependent mechanism, and in the process, transforms the cell [51].

The E6 gene promotes the degradation of the tumorsuppressor gene, p53 (or TP53), by interacting with the E3 ubiquitin ligase, the E6-associated protein (E6AP), whereas the E7 gene binds to the retinoblastoma protein $(\mathrm{pRb})$, disrupting its complex formation with the E2F transcription factors (proteins responsible for normal cell development and which codify the DNA synthetic phase in eukaryotes) [47]. In doing so, the cell loses its capability to suppress the formation of a tumor.

The E7 increases the p16 expression, which can be used to detect cancers [52], as the tumor-suppressor p16 gene is usually easily modified (for example, by deletion or replication errors) at the onset of cancer [53-54].

The entire process of oncogenesis may take a long time to occur, depending on the individual's lifestyle and immune status. WHO [46] estimates the process of carcinogenesis in the cervix to span between 15 and 20 years in immunocompetent women, and 5-10 years in immunocompromised women, such as those with untreated HIV infection. The United States National Cancer Institute [45] estimates about 10-20 years generally for HPV to cause the development of tumors.

\subsection{Sexually-Transmitted Bacteria Causing Cancer: Chlamydia Trachomatis as a Representative Member}

Chlamydia trachomatis is a weakly Gram-negative, obligate intracellular parasite. The bacterium is a non-motile, ovoid bacterium. Although it is a non-spore-forming 
bacterium, its inclusion bodies can act as spores when inside the host. Many have plasmids. C. trachomatis causes a host of infections including Chlamydia infection, nongonococcal urethritis, cervicitis, salpingitis, and pelvic inflammatory disease [55]. As shown in table 1, they also cause cancers such as lymphogranuloma venereum, cervical cancer, ovarian cancer, and trachoma [56].

C. trachomatis exists in three human biovars. These biovars are: serovars $\mathrm{Ab}, \mathrm{B}, \mathrm{Ba}$, and $\mathrm{C}$ [57], which cause trachoma, an eye infection that could lead to irreversible blindness [58]; serovars D, E, F, G, H, I, J, K, which cause proctitis, salpingitis, urethritis, pelvic inflammatory disease, neonatal pneumonia, and neonatal conjunctivitis; and serovars L1, L2, and L3, which are implicated in lymphogranuloma venereum [58].

Chlamydia is transmitted by vaginal, anal or oral sex, and can also be transmitted vertically during childbirth [55]. Members of the species have a high propensity for genetic exchange among strains, and as a result, new strains are regularly produced [59].

Scientists are still carrying out studies to be sure of the specific mechanisms of several bacteria in causing cancer, but there are some hypotheses [61]. Oncogenic bacteria cause genetic damage and neoplastic changes when cultured in vitro with body cells [61]. Although it is tempting to conclude that this is a way to identify oncogenic cells, however, there might be several other bacteria that elicit the same response on the body cells, and a general speculation might be misleading. Nonetheless, researchers have repeatedly confirmed that when a person has pelvic inflammatory disease (PID), there is an increase in serum level of tumor markers TATI (tumor-associated trypsin inhibitor), and CA-125, associated with ovarian cancer [6263] and C. trachomatis has been implicated in about $30 \%$ of all cases of PID [64].

C. trachomatis is mainly associated with cervical cancer, the $\mathrm{G}$ serotype is most associated with squamous ovarian cell cancer, and patients whose serum contain antibodies to more than one type of Chalmydia trachomatis have a greater chance of developing cancer [65-66].

C. trachomatis often infects endocervical glandular cells, and women with cervical ectopy, and it is rather unusual for it to cause cancer in squamous cells [60, 67]. However, research has proven that it does anyway, through a process known as squamous cell metaplasia, and it also causes cancer in metaplasic cells [60]. Persistent chlamydial infection, for example, through repeated infection, and immunodepletion, may also induce squamous metaplasia, and metaplasic cell atypia, and the process of oncogenesis by C. trachomatis could also takes years or decades $[60,68]$.

Another method that $C$. trachomatis employs in causing cancer is the inhibition of cell apoptosis [69]. Experiments carried out by Fan et al. [69] reveal that when C. trachomatis infects the cell, apoptosis is inhibited but internally, and when external factors, such as staurosporine (which strongly induces apoptosis) were manually introduced. It is speculated that the organism inhibits apoptosis by inhibiting the activation of caspase 3 , one of the crucial downstream members of the aspartate-specific cysteine protease family, which is believed to be critical to apoptosis [70]. They are, however, unsure, whether the caspase 3 is directly inhibited, or whether it is the upstream steps leading to its activation that are affected.

Another way of inhibiting cellular apoptosis is through the inhibition of mitochondrial cytochrome $\mathrm{c}$, which may be crucial to cellular apoptosis [71]. How this is achieved is unknown, but different researchers have come up with 3 hypotheses: first, it could inhibit the upstream steps that control normal functions of mitochondria by producing different antiapoptotic factors [72-74].

The second hypothesis is that the infection could upregulate expression of mitochondrial $\mathrm{Bcl}-2$ or Bcl-2-like molecules, because these membrane proteins are known to prevent both the activation of caspase and prevention of cytochrome c release [69]. However, it is not every time that overexpression of $\mathrm{Bcl}-2$ protects from Fas cross-linkinginduced apoptosis [75-76], nor does it always block apoptosis [77].

Thirdly, they believe Chlamydia may produce other antiapoptosis factors that are not yet discovered or understood [69].

\subsection{Sexually-Transmitted Fungi Causing Cancer: Candida albicans as a Representative Member}

Candida albicans is the most common member of about 20 species of infectious Candida yeasts [78]. It is a component of the normal body flora in most humans, and can remain in immunocompetent persons without causing an infection. It is an opportunistic organism, ususally causing infection when the immune system is impaired. Symptoms of Candida infection vary, depending on the part of the body infected, and may include: weight gain, joint pain, fatigue, bloating, headache and nausea [78]. Candidiasis can occur in the mouth (oral thrush), vagina (vaginal thrush), or in the bloodstream, from where it circulates all over the body (invasive candidiasis) [78].

C. albicans can cause an infection when excess of it is consumed, for example, in food products; it can be transmitted vertically, and from then on, it becomes a gut flora in the child; it can also be sexually-transmitted. The yeast is particularly difficult to treat for many reasons. First, it is a eukaryotic cell, just like the human cell, and therefore most drugs that would be toxic to it can easily be toxic to the human cell as well. Secondly, it exhibits polymorphismduring unfavourable conditions, or when a drug is targeted at it, it would transform to another form that is most convenient for it - and this makes it very difficult to eliminate by many drugs [79-80]. The yeast form thrives best in an acidic environment, and is the form that is mostly transmitted among people, while the filamentous form is best suited for an alkaline or neutral $\mathrm{pH}$, and is the form that results in candidiasis. It can also exist as pseudohyphae, the role of which is not properly understood, apart from the fact that it is an intermediate state between the yeast form and the hyphal 
form [81].

C. albicans has been found to employ at least four mechanisms in causing cancer to body cells. These include:

\subsubsection{Production of Carcinogenic By-Products}

C. albicans produces nitrosamines, carcinogens which activate lesion-triggering proto-oncogenes. Acetaldehyde, the product of fermentation, is another metabolite produced by this organism. It damages the DNA, and is a known carcinogen when in large quantity [82-83].

\subsubsection{Triggering of Inflammation}

When inflammation is continuous and prolonged, it can lead to cancer by damaging tissues and secretion of chemicals that enhance cell proliferation, which, instead of repairing damaged tissue, actually make the tissue immortal when the inflammation is chronic and endless [84].

\subsubsection{Induction of TH17 Response}

TH17 cells are the major CD4 cells that respond to $C$. albicans invasion. They also secrete blood vessel-forming factors (a process known as "angiogenesis"), and promote the onset of cancer and the growth of cancer cells [83].

\subsubsection{Molecular Mimicry}

The CR3-RP, a compliment receptor 3-related protein, in C. albicans is similar to the human $\mathrm{C} 3$ proteins expressed in monocytes, macrophages and neutrophils, because, just like them, it can bind to human complement fragment iC $3 \mathrm{~b}$ [85]. As a result of this similarity, the body might produce antibodies against body antigens, when it cannot differentiate the body's antigens from those of the fungus, and while destroying these vital defense cells, the body's defense gets significantly weakened and it loses its ability to fight against invaders and the development of cancer cells $[83,85]$.

\subsection{Sexually-Transmitted Protozoa Causing Cancer: Trichomonas vaginalis as a Representative Member}

Trichomonas vaginalis, an anaerobic organism that is implicated in causing trichomoniasis, a sexually transmitted infection. In a study, $85 \%$ of women living with trichomoniasis were asymptomatic [86]. Symptoms can start manifesting between 5 and 28 days, but can also start later [86]. The symptoms include itchy, inflamed and burning genitals, genital discharge, and burning during urination. This infection can cause premature delivery in pregnant women, or underweight babies [87]. Among other infections, this organism can cause cervical neoplasia, a precancerous condition characterized by the growth of abnormal cells on the surface of the cervix [88].

More importantly, researchers have connected $T$. vaginalis with cancer. Although T. vaginalis is the most studied trichomonad and much is known about trichomoniasis, scientists are still uncertain about the specific molecular mechanisms. However, based on existing evidence, Sutcliffe et al. (2012) [89] have put forward 2 hypotheses: first, that the inflammation caused by this organism may contribute to the onset of cancer of the prostate, as inflammation is one of the major trigger factors of prostate cancer. Second, that by binding of specific adhesins of $T$. vaginalis to normal prostate epithelial cells (PECs), a cell-signaling cascade is triggered through three known proto-oncogenes named HMGA1, cMYC, and PIM1, and this may eventually result in prostate cancer. These hypotheses are discussed as follows:

\subsubsection{Inflammation}

When cells are infected with $T$. vaginalis, there is an influx of leukocytes and chronic inflammation [89]. When the organism adheres to vaginal epithelial cells (VECs), the expression of monocyte chemoattractant protein-1, and interleukin-8 (IL-8), both of which are pro-inflammatory cytokines which play an important role in inducing neutrophils [89]. Also, studies have found high concentrations of IL-8, leukotriene B4, d neutrophils, in vaginal secretions of those positive for this infection. The neutrophils may secrete some oxygen- and nitrogen-based reactive molecules that can damage the DNA and adjacent cells, and this may contribute to oncogenesis [89].

It has been shown that when T. vaginalis adheres to epithelial cells, IL-6 (an important inflammatory mediator associated with prostate cancer) count rises [89]. In essence, this organism causes the influx of pro-inflammatory molecules, which may play a role in carcinogenesis.

\subsubsection{Oncogene Mediation}

Three oncogenes have been identified:

(i) PIM1

The protein encoded by this gene belongs to a unique group of serine/threonine kinases, which are special because they are constitutively active. Not only does the expression of this gene lead to genomic instability, it can cause an abnormal cell to survive under highly unfavorable conditions, thereby preserving the cancerous cell [90-91]. Because increased levels on this gene were observed in prostate cancer patients compared to non-cancer patients, it is believed that the gene may play a role in the onset of prostate cancer [89].

(ii) HMGA1

It encodes a chromatin "architectural transcription factor" that, acts downstream of PIM1 in an HMGA1-mediated prostate cancer induction pathway [89, 92]. When the cMYC is phosphorylated by the PIM1 kinase, the c-MYCPIM1 complex binds to the "E box" in the promoter of cMYC target genes, such as HMGA1, and cause them to be transcribed [89]. The c-MYC and HMGA1 have also been seen to be overexpressed in prostate cancer patients [93], and are associated with in vivo metastasis and an increased rate of cell multiplication [94-95].

Studies suggest that the HMGA1 may play a role in chromosomal mutations of prostate cells, and that it may regulate some of the genes that are important in cell transformation and metastatic tumor progression [89, 96]. The effects of this gene may be more strongly felt, because the activation of the STAT3 gene promoter may lead to a chronic self-enforcing feedback stimulatory loop, resulting in 
the overexpression of the HMGA1 gene [97]. Also, because T. vaginalis upregulates the expression of the HMGA1 gene in prostate epithelial cells, it may also play a role in oncogenesis as part of the PIM1 $\rightarrow$ c-MYC $\rightarrow$ HMGA1 signaling cascade $[42,98]$.

Another way in which this pathogen may lead to prostate cancer is in the fact that the transcription of the gene is induced when the cell is stressed [89], and when there is inflammation mediated by the IL- 6 , and the pathogen naturally induces the IL- 6 in prostate epithelial cells, which would normally cause the said inflammation, and, consequently, the transcription of the HMGA1 gene. [89] hypothesize that the IL- 6 stimulation is done by the binding of the HMGA1 to the IL- 6 promoter, which has binding sites for the protein. This promotes increased expression of the IL6 , which may reinforce the cascade, and contribute to the progression of cancer in the prostate, by a separate, related mechanism.

(iii) $\mathrm{COX}-2$

T. vaginalis induces the expression of COX-2 in primary human vaginal epithelial cells [89]. Research has shown that expression of the COX-2 gene is induced in epithelial cells when the cell receptors interact with AP65, a T. vaginalis adhesion, and this reaction may result in prostate cancer. The HMGA1 also upregulates the expression of the COX-2 [99], the overexpression of which has been associated with initiation and progression of cancers of the breast [100], colorectum, esophagus, head, neck, and prostate; as well as prostatic hyperplasia, non-small-cell cancer of the lungs [42]. COX-2 gene may also interfere with normal cell division rates, mitosis, adhesion, immune surveillance, and programmed cell death.

Polyamines such as putrescine, naturally secreted in large amounts by this organism during its growth, regulate the amount of the COX-2 in human airway epithelial cells, and also play a role in cell cycle regulation in various types of cancer, causing them to proliferate abnormally [101-102].

\section{Conclusion and Recommendations}

Several disease pathogens have been associated with inducement of cancer in their host, and while the specific mechanisms of action of some of these organisms have been discovered, research is ongoing to identify or confirm the mechanisms of action of others. With the exception of cancers caused by mutation genes within the individual, most cancers are preventable by leading wholesome and healthy lifestyles. It is also quite logical that prevention of the cancer-causing sexually-transmitted infections will consequently prevent the cancer caused by the disease or pathogen. Aside the other measures of preventing STIs, having a mutually-monogamous sexual relationship with an uninfected individual is perhaps the most important step in preventing these infections, and by extension, the cancers caused by them. Getting the available vaccines will also prevent most of these diseases and prevent the cost and pain incurred during treatment.
Specific recommendations are as follows:

1. Getting Tested: One should get tested for all the sexually-transmitted infections there are. Early detection is key in treatment success.

2. Use of condoms during sexual intercourse with an individual whose status is not yet confirmed with acceptable laboratory tests will significantly reduce the chance of getting infected with an STI.

3. Consistency: Being in a mutually monogamous relationship with an uninfected partner is a way not to be infected with STIs and their consequences.

4. Sterile Equipment: Using sterile medical and beauty equipment and not sharing sharp or invasive objects that can transmit pathogens.

5. Getting Vaccinated: By being vaccinated, your body acquires immunity to these infections.

6. Adherence to Treatment Regimen: In the case of an infection, strict adherence to the treatment regimen prevents the organism from getting acquainted with the drug and developing ways to resist the drug.

\section{Conflicts of Interest}

The authors report no conflicts of interest.

\section{Funding Statement}

The authors received no funding.

\section{References}

[1] United States National Institutes of Health (2017) What are Some Types of and Treatments for Sexually Transmitted Diseases (STDs) or Sexually Transmitted Infections (STIs)? Available online: https://www.nichd.nih.gov/health/topics/stds/conditioninfo/typ es. Accessed 26-02-2020, 9: 50 hours.

[2] World Health Organisation (2019) Sexually Transmitted Infections (STIs). Available onlline: https://www.who.int/news-room/fact-sheets/detail/sexuallytransmitted-infections-(stis). Accessed 26-02-2020, 10: 08 hours.

[3] World Health Organisation. Cancer. Available online: https://www.who.int/cancer/en/. Accessed 20-01-2019, 19: 42 hours.

[4] United States National Cancer Institute (2015) What is Cancer? Available: www.cancer.gov/aboutcancer/understanding/what-is-cancer. Accessed 27-12-2017, 19: 00 hours.

[5] Paul, C., Mistriotis, P. and Konstantatopoulos, K. (2017) Cancer Cell Motility: Lessons from Migration in Confined Spaces. Nature Reviews-Cancer. 17 (2): Pp 131-140. DOI: http://dx.doi.org/10.1038/nrc.2016.123.

[6] World Health Organisation Media Centre (2017b) Fact sheet: The Top 10 Causes of Death. Available: www.int/mediacentre/factsheets/fs310/en/. Accessed 27-122017. 
[7] World Health Organisation (2017) 10 Facts About Cancer. Available online: https://www.who.int/features/factfiles/cancer/en/. Accessed 25-02-2020, 13: 13 hours.

[8] World Health Organisation (2018) Cancer. Available online: www.who.int/news-room/fact-sheets/detail/cancer. Accessed 08-10-2018.

[9] De Martel, C., Ferlay, J., Franchesci, S., Vignat, J., Bray, F., Forman, D. et al. (2012) Global Burden of Cancers Attributable to Infections in 2008: A Review and Synthetic Analysis. The Lancet-Oncology. DOI: https://doi.org/10.1016/S1470-2045(12)70137-7.

[10] Stolte, M., Bayerdörffer, E., Morgner, A., Alpen, B., Wündisch, T. Thiede, C. and Neubauer. Helicobacter and Gastric MALT Lymphoma. Gut. 50 (Suppl III): Ppiii19-iii24. DOI: http://doi.org/10.1136/gut.50.suppl_3.iii19.

[11] Crowe, S. E. (2005) Helicobacter Infection, Chronic Inflammation, and the Development of Malignancy. Current Opinions in Gastroenterology. 1: 32-8.

[12] Correa, P. and Piazuelo, B. (2011) Helicobacter pylori Infection and Gastric Adenocarcinoma. US Gastroenterology and Hepatology Review. 7 (1): Pp 59-64. PMID: 21857882.

[13] Callaway, E. (2012) E. coli Strain Linked to Cancer in Mice. Nature-News. http://doi.org/10.1038/nature.2012.11211.

[14] American Cancer Society (2016a) Bacteria That Can Lead to Cancer. Available online: www.cancer.org/cancer/cancercauses/infectious-agents/infections-that-can-lead-tocancer/bacteria.html. Accessed 08-10-2018.

[15] El-Mosalamy, H., Salman, T. M., Ashmawey, A. M. and Osama, N. (2012) Role of Chronic E. coli Infection in the Process of Bladder Cancer- An Experimental Study. Infectious Agents and Cancer. 7: 19. DOI: http://doi.org/10.1186/17509378-7-19.

[16] Meehan, B. (2016) What You Can Do to Reduce the Risk of Bowel Cancer Caused by E. coli Bacteria. The Conversation. Available online: https://theconversation.com/amp/what-youcan-do-to-reduce-the-risk-of-bowel-cancer-caused-by-e-colibacteria-60264. Accessed 08-12-2018, 21: 55 hours.

[17] Mischaud, D. S., Platz, E. A. and Giovannucci, E. (2007) Gonorrhoea and Male Bladder Cancer in a Prospective Study. British Journal of Cancer. 96: Pp 169-171. DOI: http://10.1038/sj.bjc.6603510.

[18] Lian, W-Q., Luo, F., Song, X-L. and Zhao, S-C. (2015) Gonorrhoea and Prostate Cancer Incidence: An Updated Meta-Analysis of 21 Epidemiologic Studies. Medical Science Monitor. 21: Pp 1895-1903. DOI: http://doi.org/10.12659/MSM.893579.e-ISSN 1643-3750.

[19] Zhu, H., Shen, Z., Luo, H., Zhang, W. and Zhu, X. (2016) Chlamydia trachomatis Infection-Associated Risk of Cervical Cancer: AA Meta-Analysis. Medicine. 95 (13): e3077.

[20] Das, M. (2018) Chlamydia Infection and Ovarian Cancer Risk. The Lancet-Oncology. 17 (7): Pe 338. DOI: https://doi.org/10.1016/S1470-2045(18)30421-2.

[21] Trabert, B. Waterboer, T., Idahl, A., Brennerm N., Brinton, L. A., Butt, J. et al. (2018) Antibodies Against Chlamydia trachomatis and Ovarian Cancer Risk in Two Independent Populations. Journal of the National Cancer Institute. 111 (2): djy084. DOI: https://10.1093/jcni/djy084.

[22] Spaargaren, J., Fennema, H. S. A., Morré, S. A., de Vries, H. J. C. and Coutinho, R. A. (2005) New Lymphogranuloma Venereum Chlamydia trachomatis Variant, Amsterdam. Emerging Infectious Diseases. 11 (7): Pp 1090-2. DOI: http://doi.org/10.3201/eid1107.040883.

[23] Huang, S., Li, J. Y., Wu, J., Meng, L. and Shou, C. C. (2001) Mycoplasma Infections and Different Human Carcinomas. World Journal of Gastroenterology. 7: Pp 266-9.

[24] Namiki, K., Goodison, S., Porvasnik, S., Allan, R. W., Iczkowski, K. A., Urbanek, C. et al. (2009) Persistent Exposure to Mycoplasma Induces Malignant Transformation of Human Prostate Cells. Plos One. 4 (9): e6872. DOI: http://doi.org/10.1371/journal.pone.0006872.

[25] Barykova, Y. A., Logunov, D. Y., Shmarov, M. M., Vinarov, A. Z., Fiev, D. N., Vinarova, N. A. et al. (2011) Association of Mycoplasma hominis Infection with Prostate Cancer. $\begin{array}{lllll}\text { Oncotarget. } 2 & \text { (4): } \quad P p & \text { 280-97. } & \text { DOI: }\end{array}$ http://doi.org/10.18632/oncotarget.256.

[26] Yang, H., Qu, L., Ma, H., Chen, L., Liu, W., Liu, C. et al. (2010) Mycoplasma hyorhinis Infection in Gastric Carcinomas and Its Effect on the Malignant Phenotypes of Gastric Cancer Cells. BMC Gastroenterology. 10: P132. DOI: http://doi.org/10.1186/1471-230X-10-132.

[27] Mitin, V., Tumanova, L. and Botnariuc, N. (2016) Mycoplasma faucium and Breast Cancer. bioRxiv. DOI: http://doi.org/10.1101/089128.

[28] Pehlivan, M., Pehlivan, S., Onay, H., Koyuncuoglu, M. and Kirkali, Z. (2005) Can Mycoplasma-mediated Oncogenesis be responsible for Formation of Conventional Renal Cell Carcinoma? Urology. 65 (2): Pp 411-4.

[29] Kumar, R., Herold, J. L., Schady, D., Davis, J., Kopetz, S. Martinez-Moczygemba et al. (2017) Streptococcus gallolyticus subsp. Gallolyticus Promotes Colorectal Cancer Tumour Development. Plos Pathogens. 13 (7): e1006440. DOI: https://doi.org/10.1371/journal.ppat.1006440.

[30] Koshiol, J., Wozniak, A., Cook, P., Adaniel, C., Acevedo, J, Azócar, et al. (2016) Salmonella enterica serovar typhi and gallbladder cancer: a Case-Control Study and Meta-Analysis. Cancer Medicine. 5 (11): $\mathrm{Pp}$ 3310-25. DOI: http://doi.org/10.1002/cam4.915.

[31] Di Domenico, E. G., Cavallo, I., Pontone, M., Toma, L. and Ensoli, F. (2017) Biofilm Producing Salmonella typhi: Chronic Colonisation and Development of Gallbladder Cancer. International Journal of Molecular Sciences. 18 (9): P1887. DOI: https://doi.org/10.3390/ijms18091887.

[32] Mughini-Gras, L., Schaapveld, M., Kramers, J., Mooij, S., Neefjes-Borst, E. A., Pelt, W. V. et al. (2018) Increased Colon Cancer Risk After Severe Salmonella Infection. Plos One. 13 (1) e0189721. DOI: http://doi.org/10.1371/journal.pobe.0189721.

[33] American Cancer Society (2016b) Viruses That Can Lead to Cancer. Available online: www.cancer.org/cancer/cancercauses/infectious-agents/infections-that-can-lead-tocancer/viruses.html. Accessed 08-10-2018.

[34] DeNoon, D. J. (2011) Higher Cancer Risk in People With HIV. WedMD. Available online: https://webmd.com/hivaids/news/20111122/higher_cancer_risk_in_people_with_hiv. Accessed 10-10-2018. 
[35] Mesri, E. A., Cesarman, E. and Boshoff, C. (2010) Kaposi's Sarcoma Herpesvirus/Human Herpesvirus-8 (KSHV/HHV8) and the Oncogenesis of Kaposi's Sarcoma. Nature ReviewsCancer. 10 (10): Pp 707-19.

[36] Rafferty, K. A. Jnr. (1973) Herpes Viruses and Cancer. Scientific American. 229 (4): Pp 26-33.

[37] Herbein, G. and Kumar, A. (2014) The Oncogenic Potential of Human Cytomegalovirus and Breast Cancer. Frontiers in Oncology. $\quad 4: \quad$ P230. http://doi.org/10.3389/fonc.2014.00230.

[38] Geder, K. M., Lausch, R., O’Neill, F. and Rapp, F. (1976) Oncogenic Transformation of Human Embryo Lung Cells by Human Cytomegalovirus. Science. 192: Pp 1134-7.

[39] Michaelis, M., Doerr, H. W. and Cinatl, J. (Jr.) (2009) The Story of Human Cytomegalovirus and Cancer: Increasing Evidence and Open Questions. Neoplasia. 11 (1): Pp 1-9.

[40] Wolfe, D. (2016). Is There A Link between Candida albicans and Cancer? The Truth about Cancer. Available online: https://thetruthaboutcancer.com/candida-albicans-cancer/. Accessed 09-12-2018, 23: 42 hours.

[41] Chung, L-M., Liang, J-A., Sun, L-M. and Kao, C-H. (2017) Cancer Risk in Patients with Candidiasis: A Nationwide Population-Based Cohort Study. Oncotarget. 8 (38): Pp 63562-63573.

[42] Gupta, R., Nowakowski, M. and Haseeb, M. A. (2015) Infection and Cancer: Bi-Directorial Interactions. Springer. In: Shurin, M. R., Thanavala, Y. And Ismail, N. (Ed.). eBook ISBN: 978-3-31920669-1.

[43] Tsang, S. H., Peisch, S. F., Rowan, B., Markt, S. C., GonzalezFeliciano, A. G., Sutcliffe, S. et al. (2018) Association Between Trcihomonas vaginalis and Prostate Cancer Mortality. International Journal of Cancer. Preprint. DOI: http://doi.org/10.1002/ijc.31885.

[44] Münger, K., Balbwin, A., Edwards, K. M., Hayakawa, H., Nguyen, C. L., Owens, M. et al. (2004) Mechanisms of Human Papillomavirus-Induced Oncogenesis. Journal of $\begin{array}{llllll}\text { Virology. } & 78 & \text { (21): } \quad \text { Pp 11451-11460. } & \text { DOI: }\end{array}$ https://doi.org/10.1128/JVI.78.21.11451-11460.2004.

[45] United States National Cancer Institute. HPV and Cancer. Available online: https://www.cancer.gov/aboutcancer/causes-prevention/risk/infectious-agents/hpv-andcancer. Accessed 22-04-2018.

[46] World Health Organisation Media Centre (2016) Fact sheet: sexually transmitted infections. Available: www.who.int/mediacentre/factsheets/fs110/en/. Accessed 2612-2017.

[47] Narisawa-Saito, M. and Kiyono, T. (2007) Basic Mechanisms of High-Risk Human Papillomavirus-Induced Carcinogenesis: Roles of E6 and E7 Proteins. Cancer Science. 98 (10): Pp 1505-11.

[48] Selcuk, O. T. (2016) Human Papillomavirus-Positive Oropharyngeal Cancer: the General Information. Egyptian Journal of Ear, Nose, Throat, and Allied Sciences. 17 (3). Pp. 127-132. DOI: https://doi.org/10.1016/j.ejenta.2016.07.007.

[49] Lehoux, M., D'Abramo, C. M. and Archambault, J. (2009) Molecular Mechanisms of Human Papillomavirus-Induced Carcinogenesis. Canadian Institutes of Health Research.
Public Health Genomics. 12 (5-6): Pp 268-280. DOI: http://dx.doi.org/10.1159/000214918.

[50] Oh, J., Kim, J., Cho, E., Song, Y., Kim, W. and Juhnn, Y. (2010) Human Papillomavirus Type 16 E5 Protein Inhibits Hydrogen Peroxide-Induced Apoptosis by Stimulating Ubiquitin-Proteasome-Mediated Degradation of Bax in Human Cervical Cancer Cells. Carcinogenesis. 31 (3): Pp 402-10. DOI: https://doi.org/10.1093/carcin/bgp318.

[51] DiMaio, D. and D. Mattoon (2001) Mechanisms of Cell Transformation by Papillomavirus E5 Proteins. Oncogene 20: 7866-7873.

[52] Benson, E., Li, R., Eisele, D. and Fakhry, C. (2014) The Clinical Impact of HPV Tumor Status Upon Head and Neck Squamous Cell Carcinomas. Oral Oncology. 50: Pp 565-574.

[53] The United States National Library of Medicine (2018) CDKN2A Gene: Cyclin-Dependent Kinase Inhibitor 2A. Available: https://ghr.nlm.nih.gov/gene/CDKN2A. Accessed 14-02-2018.

[54] Matsumura, Y., Nishigori, C., Imamura, S. and Takebe, H. (1998) Mutations of p16 and p15 Tumor-Suppressor Genes and Replication Errors Contribute Independently to the Pathogenesis of Sporadic Malignant Melanoma. Archives of


https://www.ncbi.nlm.nih.gov/pubmed/9617435.

[55] Centres for Disease Control and Prevention (2017a) Gonorrhoea- CDC Fact Sheet (Detailed Version). Available online: www.cdc.gov/std/gonorrhoea/stdfact-gonorrhoeadetailed.htm. Accessed 09-10-2018.

[56] Graeter, L., Hertenstein, E., Accurso, C. and Labiner, G. (2014) Elsevier's Medical Laboratory Science Review (e-Book). Elsevier Health Sciences. P. 30. ISBN: 9780323292412.

[57] Fredlund, H., Falk, L., Jurstrand, M. and Unemo, M. (2004) Molecular Genetics Methods for Diagnosis and Characterisation of Chlamydia trachomatis and Neisseria gonorrhoeae Impact on Epidemiological Surveillance and Interventions. APMIS: Acta Pathologica Microbiologica et Immunologica Scandinavica. 112 (11-12): Pp 771-84. DOI: http://doi.org/10.1111/j.1600-0463.2004.apm11211-1205.x. PMID: 15638837.

[58] World Health Organization Media Centre (2017c) Trachoma. Available: http://www.who.int/mediacentre/factsheets/fs382/en/. Accessed 04-02-2018.

[59] Joseph, S. J., Didelot, X., Rothschild, J., de Vries, H. J. C., Morré, Read, T. D. and Dean, D. (2012) Population Genomics of Chlamydia trachomatis: Insights on Drift, Selection, Recombination, and Population Structure. Molecular Biology and Evolution. 29 (12): Pp 3933-3946. DOI: http://doi.org/10.1093/molbev/mss198.

[60] Paavonen, J. (2001) Chlamydia trachomatis and Cancer. Sexually Transmitted Infections. 77: Pp 154-156.

[61] Rosin, M. P., Anwar, W. A. and Ward, J. A. (2001) Inflammation, Chromosomal Instability and Cancer: the Schistosomiasis Model. Cancer Research. 54 (Suppl 7): Pp 1929-33.

[62] Paavonen, J., Miettinen, A. and Heinonen, P. K. (1989) Serum CA 125 in Acute Pelvic Inflammatory Disease. British Journal of Obstetrics and Gynecology. 96: Pp 574-9. 
[63] Paavonen, J., Kiviat, N. and Wölner-Hanssen, P. (1988) Colposcopic Manifestations of Cervical and Vaginal Infections. Obstetrical and Gynecological Survey. 43: Pp 37381 .

[64] Herzog, S. A., Althaus, C. L., Heijne, J. C. M., Oakeshott, P., Kerry, S., Hay, P. and Low, N. (2012) Timing of Progression from Chlamydia trachomatis Infection to Pelvic Inflammatory Disease: A Mathematical Modelling Study. BMC Infectious Diseases. 12: Pp 187. DOI: https://doi.org/10.1186/14712334-12-187.

[65] Risch, H. A., Marrett, L. D. and Howe, G. R. (1994) Parity, Contraception, Infertility, and Risk of Epithelial Ovarian Cancer. American Journal of Epidemiology. 140: Pp 585-97.

[66] Anttila, T., Saikku, P. and Koskela, P. (2001) Serotypes of Chlamydia trachomatis and the Risk for the Development of Cervical Squamous Cell Carcinoma. JAMA. 285: Pp 47-51.

[67] Smelov, V., Sundstom, K., Ploner, A., McKay-Chopin, S., Eklund, C., Tommasino, M. and Dillner, J., (2016) Lack of Significant Effects of Chlamydia trachomatis Infection on Cervical Adenocarcinoma Risk: Nested Case-Control Study. Plos One. DOI: https://doi.org/10.1371/journal.pone.0156215.

[68] Kiviat N., Paavonen J. and Brockway J. (1985) Cytologic Manifestations of Vaginal and Cervical Infections: Epithelial and Inflammatory Cellular Changes. JAMA. 253: P989.

[69] Fan, T., Lu, H., Hu H., Shi, L., McClarty, G. A., Nance, D. M. et al. (1998) Inhibiton of Apoptosis in Chlamydia-Infected Cells: Blockade of Mitochondrial Cytochrome c Release and Caspase Activation. The Journal of Experimental Medicine. 187: $\quad$ Pp $487-96 . \quad$ DOI: http://dx.doi.org/10.1084/jem.187.4.487.

[70] Henkart, P. A. (1996) ICE Family Proteases: Mediators of All Apoptotic Cell Death? Immunity 4: Pp 195-201, PMID: 8624810 .

[71] Zou, H., Henzel, W. J., Liu, X., Lutsch, A. and Wang, X. (1997) Apaf-1, a Human Protein Homologous to C. elegans CED-4, Participates in Cytochrome c-Dependent Activation of Acaspase-3. Cell. 90: 405-413.

[72] Shi, L., Chen, G., MacDonald, G., Bergeron, L., Li, H., Miura, M. et al. (1996) Activation of an Interleukin 1 Converting Enzyme-Dependent Apoptosis Pathway by Granzyme B. Proceedings of the National Academy of Sciences of the United States of America. 93: 11002-11007.

[73] Kroemer, G., Zamzami, N. and Susin, S. A. (1997) Mitochondrial Control of Apoptosis. Immunology Today. 18: Pp 44-51, PMID: 9018974.

[74] Rasmussen, S. J., Eckmann, L., Quayle, A. J., Shen, L., Zhang, Y. X., Anderson. et al. (1997) Secretion of Proinflammatory Cytokines by Epithelial Cells in Response to Chlamydia Infection Suggests a Central Role for Epithelial Cells in Chlamydial Pathogenesis. Journal of Clinical Investigation. 99: Pp 77-87.

[75] Strasser, A., Harris, A. W., Huang, D. C, Krammer, P. H. and Cory, S. (1995) Bcl-2 and Fas/APO-1 Regulate Distinct Pathways to Lymphocyte Apoptosis. European Molecular Biology Organisation. 14: 6136-6147, PMID: 8557033.

[76] Chiu, V. K., Walsh, C. M., Liu, C. C., Reed, J. C. and Clark W. R. (1995) Bcl-2 Blocks Degranulation but Not Fas-Based Cell-Mediated Cytotoxicity. The Journal of Immunology. 154:
Pp 2023-2032. PMID: 7532659.

[77] Erhardt, P. and Cooper, G. M. (1996) Activation of CPP32 Apoptotic Protease by Distinct Sgnaling Pathways with Differential Sensitivity to Bcl-Xl. The Journal of Biological Chemistry. 271: Pp 17601-4.

[78] Centres for Disease Control and Prevention (2017b) Fungal Diseases. Available online: http://www.cdc.gov/fungal/diseases/candidiasis/index.html. Accessed 20-01-2019, 23: 04 hours.

[79] Kurzai, O., Schmitt, C., Frosch, M. and Kolb-Maurer, A. (2005) Polymorphism of Candida albicans is a Major Factor in the Interaction With Human Dendritic cells. International Journal of Medical Microbiology. 295 (2): Pp 121-7.

[80] Villar, C. C., Kashleva, H. and Dongari-Bagtzoglou, A. (2004) Role of Candida albicans Polymorphism in Interactions with Oral Epithelial Cells. Oral Microbiology and Immunology. 19 (4): Pp 262-9.

[81] Sudbery, P., Gow, N. and Berman, J. (2004) The Distinct Morphogenic States of Candida albicans. Trends in Microbiology. 12 (7): Pp 317-24.

[82] Bakri, M. M., Hussaini, H. M., Holmes, A. R., Cannon, R. D. and Rich, A. M. (2010) Revisiting the Association Between Candidal Infection and Carcinoma, Particularly Oral Squamous Cell Carcinoma. Journal of Oral Microbiology. 2 (1): Pp 5780. DOI: http://dx.doi.org/10.3402/jom.v2i0.5780.

[83] Ramirez-Garcia, A., Rementeria, A., Aguirre-Urizar, J. M., Moragues, M. D., Antoran, A., Pellon, A. et al. (2016) Candida albicans and Cancer: Can this Yeast Induce Cancer Development or Progression? Critical Review in Microbiology. 42 (2): Pp 181-93. DOI: https://doi.org/10.3109/1040841X.2014.913004.

[84] Ji, S. (2016) Yeast is a Cause of Cancer and Turmeric Can Kill Both, Research Confirms. Green MedInfo. Available: $\mathrm{http}: / / \mathrm{www}$.greenmedinfo.com/blog/yeast-cause-cancer-andturmeric-can-kill-both-research-confirms. Accessed 06-032018.

[85] Hostetter, M. K. (2008) The iC3b Receptor of Candida albicans and its Roles in Pathogenesis. Vaccine. 26 (Suppl. 8): I108-I112. DOI: https://doi.org/10.16/j.vaccine.2008.11.056.

[86] Reed-Guy, L. and Jewell, T. (2016) Trichomoniasis. Healthline. Available online: www.healthline.com/health/trichomonas-infection.

[87] Centres for Disease Control and Prevention. STD FactsTrichomoniasis. Available online: www.cdc.gov/std/trichomonas/stdfact-trichomoniasis.htm. Accessed 08-10-2018.

[88] Soper, D. (2004) Trichomoniasis: Under Control or Undercontrolled? American Journal of Obstetrics in Gynaecology. 190 (1): Pp 281-90.

[89] Sutcliffe, S., Neace, C., Magnuson, Reeves, R., Alderete, J. F. (2012) Trichomoniasis, a Common Curable STI, and Prostate Carcinogenesis-A Proposed Molecular Mechanism. Plos


http://doi.org/10.1371/journal post.ppat.1002801.

[90] Bachmann, M. and Möröy, T. (2005) The Serine/Threonine Kinase Pim1. The International Journal of Biochemistry and Cell Biology. 37 (4): Pp 726-30. 
[91] Roh, M. Franco, O. E., Hayward, S. W., van der Meer, R. and Abdulkadir, S. A. (2008) A Role for Polyploidy in Tumorigenicity of Pim-1 Expressing Human Prostate and Mammary Epithelial Cells. Plos One. 3: c2572.

[92] Reeves R. and Beckerbauer, L. (2001) HMG1/Y Proteins: Flexible Regulators of Transcription and Chromatin Structure. Biochimica et Biophysica Acta. 1519: Pp 13-29.

[93] Hawksworth, D., Ravindranath, L., Chen, Y., Furusato, B., Sesterhenn, I. A., McLeod, D. G. et al. (2010) Overexpression of C-MYC Oncogene in Prostate Cancer Predicts Biochemical Recurrence. Prostate Cancer and Prostatic Diseases. 13 (4): Pp 311-5. DOI: http://doi.org/10.1038/pcan.2010.31.

[94] Wolfer, A. and Ramaswamy, S. (2011) MYC and Metastasis. Cancer Research. 71 (6): Pp 2034-2037. DOI: http://doi.org/10.1158/0008-5472.

[95] Pegoraro, S., Ros, G., Piazza, S., Sommaggio, R., Ciani, Y., Rosato, A. et al. (2013) HMGAl Promotes Metastatic Processes in Basal-Like Breast Cancer Regulating EMT and Stemness. Oncotarget. 14 (8): Pp 1293-1308.

[96] Schuldenfrei, A., Belton, A., Kowalski, J., Talbot, C. C. Jr., Di Cello, F., Poh, W. et al. (2011) HMGA1 Drives Stem Cell, Inflammatory Pathway, and Cell Cycle Progression Genes During Lymphoid Tumorigenesis. BMC Genomics. 12: Pp 549 .
[97] Resar, L., Dhara, S., Sumter, T. F., Mukherjee, M., Turkson, J., Jove, R. et al. (2006) STAT3: A Direct HMGA1 Gene Target Important in Lymphoid Malignancy. Blood Advances. 108: P2222.

[98] Zhang, Y, Wang, Z., Li, X. and Magnuson, N. S. (2008) Pim Kinase-Dependent Inhibition of c-Myc Degradation. Oncogene. 27: Pp 4809-4819.

[99] Tesfaye, A., Di Celso, F., Hillion, J., Ronnett, B. M., Elbahloul, O., Ashfaq, R. et al. (2007) The High Mobility Group A1 Up-regulates Cyclooxygenase 2 Expression in Uterine Tumorigenesis. Cancer Research. 67: Pp3988-4004.

[100] Singh, B., Berry, J. A., Shoher, A., Ramakrishnan, V. and Lucci, A. (2005) COX-2 Overexpression Increases Motility and Invasion of Breast Cancer Cells. International Journal of Oncology. 26 (5): Pp 1393-9.

[101] Garcia, A. F., Benchimol, M. and Alderete, J. F. (2005) Trichomonas vaginalis Polyamine Metabolism is Linked to Host Cell Adherence and Cytotoxcity. Infection and Immunity. 73 (5): Pp 2602-2610.

[102] Cowan, M. J., Coll, T. and Shelhamer, J. H. (2006) Polyamine-Mediated Reduction in Human Airway Epithelial Migration in Response to Wounding is $\mathrm{PGE}_{2}$-Dependent Through Decreases in COX-2 and $\mathrm{Cpla}_{2}$ Protein Levels. Journal of Applied Physiology. DOI: http://doi.org/10.1152/japplphysiol.01287.2005. 